\title{
Quality of Road Construction Projects in Sweden between 1990 and 2010
}

Abukar Warsame, Han-Suck Song and Hans Lind, (Royal Instititute of Technology (KTH), Sweden)

\begin{abstract}
It has been reported that productivity developments in construction are slow compared to other sectors. Measuring productivity is however not easy and it might have been underestimated due to deficiencies in the index that is used when the value added in current prices is converted into value added at constant prices. A central problem when deflating nominal prices is that the deflation should only take away price changes for identical products and not price changes related to quality changes and improvements necessitated by new environmental conditions and legislation as well as demand for higher safety. The aim of this project is to help fill this gap by looking at the quality changes over time in road construction. A combination of comparative studies and interviews with practitioners from public and private sectors that are involved in road construction projects were conducted. It was found that there had been both direct quality changes in the roads, primarily to improve safety on the roads and for noise protection, and indirect quality changes related to building in more difficult circumstances because of giving higher weight to other social objectives, especially environmental objectives. As these quality increases are not taken into account when productivity is measured, productivity improvements could be underestimated by around $1 \%$ per year.
\end{abstract}

Keywords: Productivity measurement, Quality improvements, Road construction projects

\section{Introduction}

The background for this paper is discussions about productivity in the Swedish construction sector ${ }^{1}$. As reported in Lind \& Song (2012) the conventional wisdom is that productivity development in the construction sector has been very slow compared to other sectors. The diagram below, taken from a report by the National Institute of Economic Research (2010), shows that while there was a clear trend towards increasing productivity up to the early 1990s, the figures indicate that there has been no such trend after 1996.

Measuring productivity is however not easy. Lind \& Song (2012) paper shows that productivity growth probably is underestimated due to deficiencies in the index that is used when the value added in current prices is converted into value added at constant prices. Swedish Transport Administration annual report (STA, 2010), for example, states that infrastructure condition, quality changes, new legislation and higher safety demands are some of the factors that must be taken into account in order to create a correct picture of how productivity has developed. A central problem when deflating nominal prices is that the deflation should only take away price changes for identical products and not price changes related to quality improvement. The actual quality indicators used are however very crude and therefore the price index used does not distinguish between pure inflation and price increases related to quality changes effectively. This means that reported cost increases per unit can be overestimated as it does not take into account that the higher cost can be related to increasing quality. The question becomes how much quality really has changed during the last 20 years and how large the measuring errors in the productivity figures really are. In order to answer this question, two types of projects in construction sector have been

\footnotetext{
${ }^{1}$ Bygginnovationen fas 1 (2010b), Delrapport Väg. http://www.bygginnovationen.se/sa/node.asp?node=804
} 
analysed more in detail: road construction and residential housing construction. This paper reports the study of road construction in Sweden.

Value added (SEK per hour in vertical axis), seasonally adjusted quarterly data

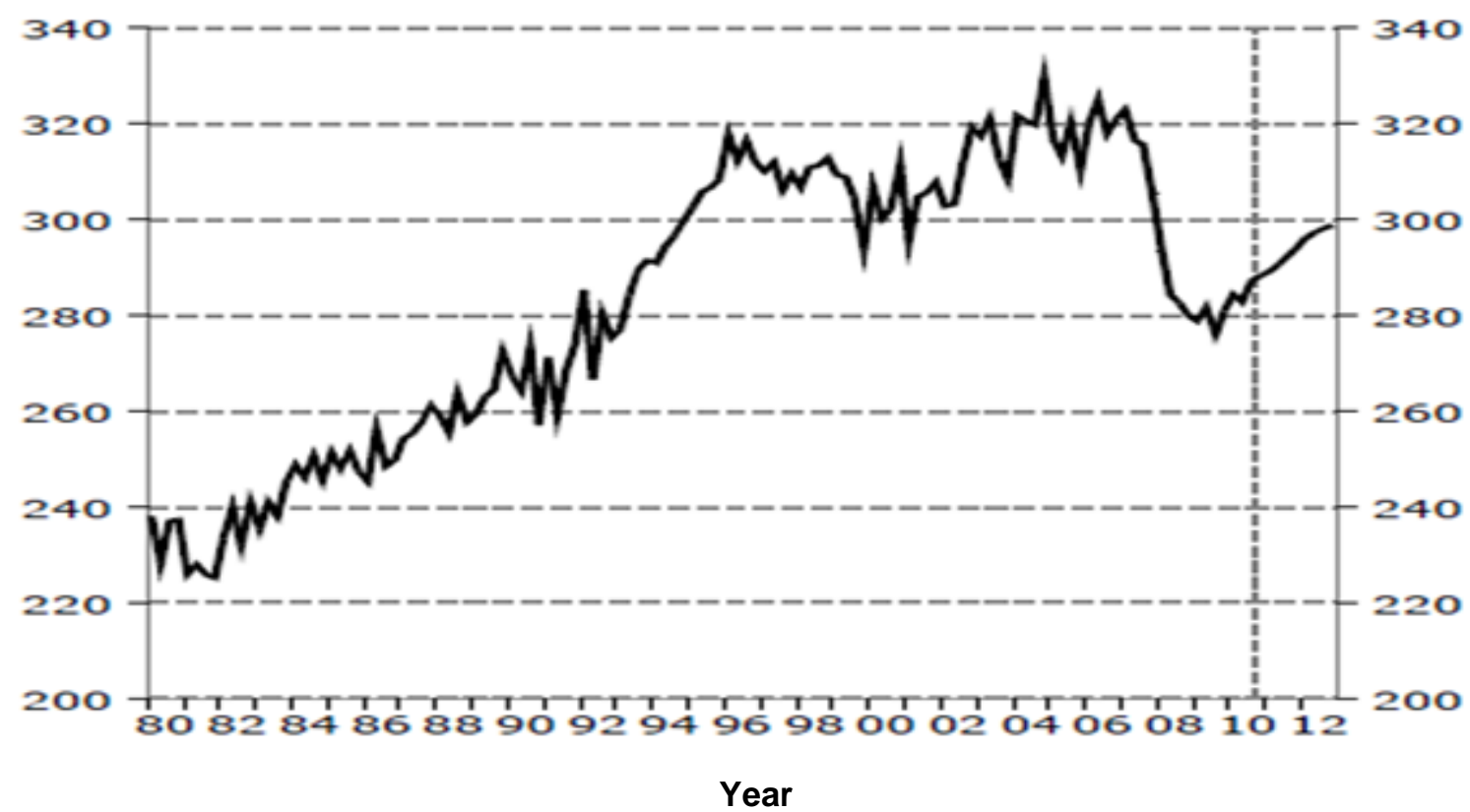

Figure 1 Productivity development in the Swedish Construction sector

(value added per hour worked). Source: SCB and National Institute of Economic Research

Cost, time and quality attributes play a big role in determining the level of project performance, and this also means that studies of quality development is of great importance. Ex-ante and ex- post project costs can provide certain indications of budgetary conformance and the development of the level of construction costs over time. For several reasons, this may not be true for the quality development aspect of construction projects. First, infrastructure projects are durable goods that last many decades and thus their performance is strongly dependent on external factors such as weather changes and usage. Secondly, quantification of quality of a construction project is hampered by lack of unique definitions and measurements. Specifications and product or user-based definitions have, for instance been used where characteristics of components of roads are specified (conformance), functionality aspect of product (fit for purpose) or certain level of user satisfaction have been met (Lay, 2009).

The aim of this project is to study the quality changes over time in road construction. Knowledge about quality changes is important both to measure the "true" level of cost increases in the sector and also to measure productivity development in a better way.

\section{Interpretation of Quality}

Warsame (2011) gives an overview of quality concepts in the construction sector and it can be noted that a common practice of measuring quality is by the absence of defects. The concept of relative quality is often used to indicate that quality is related to what you had reason to expect given the specifications made in the contract. High relative quality can then occur even in a low-price product, and the other way around. Absolute quality, on the other hand, concerns the specification and the functionality of the product over time in relation to the needs of consumers and society.

Quality changes over time can in principle refer to both relative and absolute quality. In the relative sense, quality improvements would concern primarily fewer defects. A survey 
conducted by Warsame (2011) found that there were no clear trends in relative quality over time and in this study the focus has therefore been on absolute quality. A newer project might for example include the addition of certain components such as intermediate or noise barrier that were not required in older projects. Safety demands or environmental requirements could necessitate the addition of new components or structures. In this case, incremental quality of projects is reviewed by its presence rather its absence.

It is expected that the quality of construction has changed over time due to technological changes, government regulations and user expectations. Furthermore, there is anecdotal evidence that construction costs have also increased during these periods of time. Bils and Klenow (2000) suggest that the growth rate in unit prices for any good reflects both growth in the average quality of the good and the true rate of price inflation. Inaccurate measures of construction cost increases can, as mentioned above, exacerbate the perceived productivity level of construction industry.

The paper is about quality in the form of changes in the characteristics of the road that affect the "utility" of the road. The focus here is on the quality of the road as an investment object as this is related to the direct cost and therefore the index used for calculation of productivity. In other contexts it might be more interesting to quantify quality improvement over times through more direct performance analysis, e.g. consumer satisfaction and frequency of accidents. The "utility" can concern

- People using the road: surveys are often used to elicit the level of satisfaction of road users. One major concern of deriving quality from this type of utility is the diverse opinion among road users such as private and professional drivers (STA, 2010).

- People building the road: one important quality aspect is measures taken to increase the safety of workers and road users during the construction period.

- Organisations managing the road: road infrastructures have a long life and the main concern for organisations managing them is the cost of operating and maintaining these assets. Quality improvements can take the form of more durable roads with lower life-cycle costs.

- Society at large: Ofori (1992) argues that issues related to environment should be considered as the fourth objective of construction projects. He refers to a report from Economic Commission for Europe that considered measures taken in relation to environmental issues that might increase investment costs, duration of the design and planning processes as well as the construction periods. Another societal aspect that might affect road construction costs is changes in the weight given to archaeological issues.

\section{Method}

The basic purpose is to find out the size of cost increases related to changes in quality and the work was carried out in several steps. The first step was to identify the quality changes. This was done through a combination of interviews and comparative case studies. For interviews, after a thorough discussion with different scholars, we concluded that interviews with a very experienced, reliable, and knowledgeable people are more effective and could produce better results. Thus, we have contacted five practitioners (experts) from both public and private sector that we know have had working experience with infrastructure projects.

We have conducted both semi-structured interviews and indirect communication such as emails and telephone interview with these practitioners. Our questions were very general and not specific to any projects since our aim of these interviews was to ascertain participants' views on the overall development of road construction projects since early 1990s. The aim was to identify different factors that might have affected the way we design and construct our 
road construction projects over time. Their candid and holistic view about road construction changes that took place during the last three decades also made it easier to carry out a comparative case studies, described below.

Comparison between similar roads built during in a specific region during different time periods is the other approach. Type of road and climate condition has to be kept constant in order to be able to identify quality changes. In this study the focus is on motorways in the Mälardalen region as it was expected to be rather easy to find such comparable cases. Formally, the method used is described as a multiple case study and the first step is to make a selection of projects. We chose 2 projects that were built around 1990. Secondly we chose 2 projects form the same region as before but were built a decade later, around 2000. Finally, we chose 2 more projects (same region) that were built around 2010. That made it possible to establish if certain component(s) of roads have shown significant specification changes between any two predetermined time periods. Table 1 contains the road segments that were included in the comparative analysis.

\begin{tabular}{|c|c|c|c|}
\hline Motorway & Location & Open date & Length \\
\hline E20 & Arphus - Härad & $1994-06-14$ & $6.7 \mathrm{Km}$ \\
\hline E20 & Härad -Strängnäs-Järsta & $2004-10-27$ & $13 \mathrm{Km}$ \\
\hline E4 & E-Länsgräns - Gammelsta & $1994-09-19$ & $15.6 \mathrm{Km}$ \\
\hline E4 & Björklinge - Mehedeby Etapp2 & $2007-10-17$ & $55 \mathrm{~km}$ \\
\hline E18 & Örebro -Arboga & $2000-10-31$ & $42.8 \mathrm{Km}$ \\
\hline E18 & Sagån - Enköping & $2010-10-25$ & $15 \mathrm{Km}$ \\
\hline
\end{tabular}

Table 1 Motorway projects included

Next we have obtained the descriptions and the bills of quantity of some of the selected projects. However, on the level of project description and the details of the bills of quantities, there are differences between older and newer projects.

In order to identify quality changes a list of components developed by the Swedish Transport Administration cited in Jonsson (2012) was used. The list contains six groups of component types (see table 2). Some of these components in the groups are more likely responsive to the environmental and societal demands while others are solely function of topography and specifications. For instance, changes related to the components of group 2 ("Road construction") and 4 ("Structures") are most likely influenced by topography and structure specifications rather than the utility of end-users. Unlike these two groups, group three ("Road equipment"), five ("Special installations") and six ("Road areas") could be influenced by contextual conditions such as safety requirements and traffic regulations especially when a road is classified as motorway and EU regulations must be followed. Most of major highways cross many urbanized areas, which necessitate more traffic areas and ramps, under and overpasses, as well as foot and cycle path installations to be built. Thus, group five will most likely be influenced by these factors.

Using materials from the different reports, interviews and the case studies it was however possible to find out in general what had happened with the quality of the roads built during the selected period and this is presented in the Results section below.

In the final step, our experts estimated the cost increases that this quality changes have led to and that information was used to estimate how much productivity was underestimated by the lack of information about quality changes. 


\begin{tabular}{|c|c|c|}
\hline \multicolumn{3}{|c|}{ Groups of component types } \\
\hline $\begin{array}{l}\text { Prerequisite items } \\
\text { Road zones } \\
\text { Physical planning } \\
\text { Archeological surveys } \\
\text { Traffic control devices } \\
\text { Construction administration }\end{array}$ & $\begin{array}{l}\text { Road constructions } \\
\text { Geotechnical constructions } \\
\text { Terracing, surface run-offs and } \\
\text { road-side areas } \\
\text { Superstructures }\end{array}$ & $\begin{array}{l}\text { Road equipments } \\
\text { Road markings } \\
\text { Guard rails } \\
\text { Safety barriers and wildlife } \\
\text { fences } \\
\text { Road lighting and traffic } \\
\text { signals } \\
\text { Road information structures }\end{array}$ \\
\hline $\begin{array}{l}\text { Structures } \\
\text { Bridges } \\
\text { Large culverts } \\
\text { Tunnels } \\
\text { Pile foundations } \\
\text { Support structures } \\
\text { Troughs }\end{array}$ & $\begin{array}{l}\text { Special installations } \\
\text { Protection for water catchments } \\
\text { Noise barriers } \\
\text { Foot and cycle path installations } \\
\text { Other special installations }\end{array}$ & $\begin{array}{l}\text { Road areas } \\
\text { Rest areas } \\
\text { Traffic control and information } \\
\text { areas } \\
\text { Park-and- ride car parks } \\
\text { Buildings }\end{array}$ \\
\hline
\end{tabular}

Table 2 Road components Source: Jonsson (2012)

\section{Results}

It is not feasible to compare objectively any two projects due to the dissimilarity of design characteristics, terrain and archaeological surveys, design standards for bridges and tunnels as well as other supporting structures. However, the existence of certain components in one project can be identified and cautiously interpreted as an extra improvement of performance of that project compared to another project from an earlier period that is lacking these components. Our rationalized comparison is based on the Jonsson's grouping of road components (see table 2) and it is intended to highlight some noticeable differences of construction components between two segments of same selected road construction project.

\section{Prerequisite ltems}

The two selected segments of the E 18 motorway construction projects differ in terms of their length (43 and 15 kilometres) and construction costs (878 and 590 million Swedish krona (USD ${ }^{2} 136$ and 91 million respectively). Though economies of scale associated with big projects and price increase of material and labour could be attributed to construction costs differences (21 to 39 million Swedish krona [USD3.3 and 6 million respectively] per kilometres), additional components necessitated by regulation and safety changes as well as environmental requirements could inflate the construction costs of the later project. Increase of width of roads for later projects is also another possible explanation of higher project cost. Based on the presumption that later projects were subjected to fulfil these societal and environmental demands, we were able to identify certain components of recent projects that could be seen as quality improvements.

Preservation of archaeological and cultural heritage sites has big impacts on planning of road construction projects. One of the experts (see below) has mentioned that environmental concerns have affected projects with increased costs.

\section{Road Constructions}

It was not possible to ascertain differences between these selected projects in terms of road construction components. However, several practitioners from the industry that we have asked about their opinion about changes of design and specifications of road capacity and

\footnotetext{
${ }^{2}$ Exchange rate Marsh 2014
} 
pavement strength indicated that there have been no significant changes in these aspects in the construction of roads for example the design, thickness of pavements, and specifications of structures during the last 20 years.

\section{Road Equipment}

A road safety annual report (IRTAD, 2011) explains how Sweden, over the past twenty years, succeeded in significantly increase the safety of its roads and motorways through the improvement of urban road conditions, the increased use of the " $2+1$ " roads on rural roads since 2000 , and more median barriers for motorways.

Despite that the earlier project (Örebro - Arboga) is longer than the later project (Sagån Enköping) the later project has a higher number of different types of wild life fences and access gates compare to the earlier project. It is not clear if the location of the later project dictated the erection of these components but the influence of environmental regulations cannot be ignored. IRTAD (2011) emphasized that the construction of median barriers for motorways in 2000 partly contributed the increased safety on Swedish roads. Different types of median barriers and railings were also installed at Sagån - Enköping segment that was previously described as Sweden's most dangerous road segment due its number of accidents especially head-on collisions ${ }^{3}$.

Unfortunately we were not able to access information such as the bill of quantity of ELänsgräns - Gammelsta project. Any observed differences are based on project descriptions from the E-Länsgräns - Gammelsta segment and the bill of quantity from Björklinge Mehedeby Etapp2 segment. Energy absorbent railing-ends and other crash barrier railings are a noticeable difference.

\section{Structures}

Härad -Strängnäs - Järsta segment has more bridges (8 at 38 million Swedish krona [USD6 million]) than Arphus - Härad segment (only 3 at $\sim 14$ million Swedish krona [USD 2.2 million). Topography of the terrain could necessitate construction of these many bridges but another reason could be that Härad-Järsta passes through urban areas and thus requires bridges with under and overpassing structures. It is an open question whether one should see "choosing to build in more difficult circumstances" as a kind of quality change, but it should in any case be controlled for when measuring productivity, as increasing costs might be related to such factors. Here are some excerpts from the interviews that relate to this aspect.

I think we are constructing on more complex sites with more exits, bridges, etc. (exits around cities and not in the middle of the country). In addition, environmental regulations have become tougher and obviously also increased safety and security.'

\section{Special Installations}

The Swedish Transport Administration's objective at the new constructions of roads in the vicinity of existing buildings is to meet good environment guidelines for reducing road traffic noise. Since part of the motorways studied cross urban areas, noise protection barriers were erected along residential areas to a larger extent in the later projects. It is however difficult to control for differences in the specific locations of the roads. Here are some excerpts from the interviews that relate to this aspect.

Intervention through noise barriers (dikes, screens, etc.) and median barriers has affected the cost upwards. Other environmental concerns (Natura 2000) and required

\footnotetext{
${ }^{3}$ http://www.akeritidning.se/svensk-akeritidning/nyheter/svegfors-vill-ha-permanent-overvakning-av-e18-avsnitt
} 
safeguards on other segments of road have also affected the project with increased costs.'

\section{Road Areas}

Increase of component group six such as road areas, traffic control and information areas were attributed the safety improvement of Swedish motorways. For instance, rest area with service buildings is included in one of the later projects (Sagån - Enköping at E18) with construction cost of over 3 million Swedish krona [USD 0.5 million]. Other component that is much related to road areas but is not explicitly included in Jonsson's table of road components is vegetation areas.

It is noteworthy that certain costs related to maintenance cost of road projects such as the maintenance of vegetation areas were not found in earlier projects since this type of contracts were not commonly used for older projects. Maintenance of vegetation areas (885 thousand Swedish krona [USD 137.000]) during the warranty period is included in Sagån Enköping segment. Similarly vegetation and appropriate maintenance of vegetation areas during the warranty period (amount of 1.25 million Swedish krona [USD 195.000]) is one noticeable difference between the Arphus - Härad and the Härad -Strängnäs segments.

\section{Analysis}

\section{Direct Quality Changes between 1990 and 2010}

The studies presented above indicate the following quality increases during the period under study. Focusing first on the direct changes the following characterized roads built in 2010 but not in 1990:

- middle barrier

- wild life fences

- traffic control areas

- rest and vegetation areas

The next step was then to evaluate the cost increases related to quality changes. As discussed in the method section expert opinions were relied on in this stage. The information above was then presented to experts that we have worked with earlier, followed by the question of how much lower cost would be today if these quality increases had not been made. It was clarified that this was intended to be the same question as asking how much lower costs would be today if we built the 1990-quality instead of the 2010-quality. They were given four intervals to choose between; $0-1 \%, 1-5 \%, 5-10 \%$ and more than $10 \%$. One expert suggested that if projects were built with same components and standards as 1990 projects, construction costs of current projects will be lower in the range 1-5\%. This expert added that cost reductions depend largely on the project's total budget. For small project, the reduction could certainly be between $5-10 \%$. Another expert's response was that construction cost will be lower more than $10 \%$ if we would have built current road projects with same quality as in 1990.

\section{Indirect Quality Changes}

During the project it was also found that there was another kind of indirect quality increase: that roads tended to be built in more difficult circumstances in order to satisfy other aims to a higher degree. One example is choice of location of the road. The simplest way to build might be in an attractive area from a recreational or agricultural purpose and this might have been chosen 20 years ago. But today we choose to avoid these areas and maybe build on more difficult soil conditions. A difference of this type is not covered in the approach chosen above where the focus is on technical changes. In experimental studies that are based on two large road development projects, Heldal (2007) discusses how difficult it is to choose new corridor for a road and not disturb heritage areas. The road planning process especially 
during the pre-study and inquiry phases will be affected since environmental issues are dealt with at these stages. As Smith et al. (1999) noted, environmental regulations are the outcome of a negotiated process involving different stakeholders and thus it is difficult to measure the impacts. Their study, the only one that has attempted empirically to quantify the impact of environment regulations on construction costs for road projects suggests that regulations increase delays and costs of road construction.

Direct environmental costs on E18 Muurla and Lohja motorway included in our study is estimated to be one per cent of total investment costs of the project. However, there could be other environment related costs that are part of the $4 \%$ planning costs since environmental issues are addressed during this phase. Cedermark and von Koch (2000) study, cited in VTI report $530(2006)^{4}$, indicates that the real cost of mitigation/compensation measures taken was 1 to 9 per cent of the construction cost of the road stretch. An example of this cost increase due to environmental considerations mentioned in that report is E4 segment of $27 \mathrm{KM}$ motorway that was estimated at 750 million Swedish krona [USD 116 million] but alternative designs due to environmental concerns increased the estimated cost by $3-4 \%$. In addition, one of the motorway stretches that is included in our comparative case studies (E18 Sågan-Enköpning) is also included in this VTI report with an estimated environmental cost of between 9 to 19 per cent of the total construction cost of that project. The estimated environmental cost for all the 13 case studies in the report was 8-19 per cent.

\section{Total Cost Increases Related to Quality Changes and Implications for Productivity}

Table 3 summarize these result indicating a "best guess" of a 13 percentage increase in construction costs related to changes in environmental demand and a best guess of 7 percentage increase related to new and better components in a road project. The total cost increase related to quality increases in the broad sense during the period 1990-2010 would then be roughly 20 per cent.

\begin{tabular}{|l|c|c|}
\hline \multicolumn{1}{|c|}{$\begin{array}{c}\text { Factors causing cost increase due to } \\
\text { quality changes }\end{array}$} & $\begin{array}{c}\text { Based on literature, case studies } \\
\text { and Judgment from expertise }\end{array}$ & Average \\
\hline Environment costs & 5 to 20 per cent & $13 \%$ \\
\hline $\begin{array}{l}\text { Cost of added components (railings, middle- } \\
\text { barriers, wild-life fences, rest areas, and } \\
\text { vegetation areas) }\end{array}$ & 5 to 10 per cent & $7 \%$ \\
\hline Estimated average cost increases & 10 to 30 per cent & $20 \%$ \\
\hline
\end{tabular}

Table 3 Stylized quality changes between 1990 and 2010

As we described in the introduction section, reported cost increases were just seen as increases in prices since the cost increase that is related to quality increases (as figures in Table 3 show) were not taken into consideration. When this price index then is used to deflate the value of the product, it means that productivity changes are underestimated. A neglected quality increase of 20 per cent over a 20-year period means that productivity increases has been underestimate with 0.9 per cent per year. In other words, if this undervaluation of productivity is adjusted, this will reduce the gap between productivity developments in the construction industry and other sectors.

\section{Conclusion}

The starting point for this study was weaknesses in the measurement of changes in productivity in the Swedish construction industry, where possible quality improvements were

\footnotetext{
${ }^{4}$ COST 341: Report from European Co-operation in the Field of Scientific and Technical Research http://www.vti.se/sv/publikationer/pdf/biotopfragmentering-till-foljd-av-transportinfrastrukturen-cost-341-svensknationell-kunskapsoversikt.pdf
}

Warsame, A et al (2014) 'Quality of road construction projects in Sweden between 1990 and 2010', Australasian Journal of Construction Economics and Building, 14 (1) 78-87 
not taken into account in a satisfactory way. In the presented study the focus was on the building of motorways, but in a parallel study quality changes in housing construction is studied (Borg 2013).

The first result from this study is perhaps that it was very difficult to get relevant data about the quality of road projects. The figures presented should therefore be seen as rough estimates. It was found that there have been both direct quality changes in the roads, e.g. in railings and wild life fences, primarily to improve safety on the roads, and for noise protection. It was also found that there have been indirect quality changes related to building in more difficult circumstances due to giving higher weights to other social objectives, especially environmental objectives. How much this increases cost will of course differ from project to project, but the estimate presented indicates that roads today would be around 20 per cent cheaper if they were built in the same way as 20 years ago. As these quality increases are not taken into account when productivity is measured it indicates that the yearly change in productivity is underestimated by around 1 per cent per year.

A final reservation is of course that the numbers presented are very uncertain due to lack of data, and several researchers in Sweden have pointed out that the Swedish Transport Administration has not made it easy for researcher as their data bases are incomplete and very difficult to use. In general it turned out to be much more difficult than expected to find out the qualities of the different road segments. This was partly because the Swedish Transport Administration was going through reorganisation and partly because data had not been saved in a way that made it easy to find out how the roads were built. Other researchers (Mandell and Nilsson, 2010) have also shown how badly structured is the data collected by the Swedish Transport Administration and how little is done to make evaluations possible.

\section{References}

Blis, M. and Klenow, P. (2000) Quantifying quality growth, NBER working paper No. 7695.

Borg, L. (2013) Quality change and implication for productivity development housing construction in Sweden 1990-2010, Forthcoming working paper, Building and Real Estate Economics, KTH.

Heldal, I. (2007) 'Supporting participation in planning new roads by using virtual reality system', Virtual Reality, 11 (2-3), 145-159.

IRTAD (2011) International Transport Forum, http://www.internationaltransportforum.org/, accessed on $25 / 5 / 2013$

Jonsson, P. (2012) 'Transport asset management: quality-related accounting, measurements and use in road management' process', Doctoral Thesis in Building and Real Estate Economics, KTH.

Lay, M. (2009) Handbook of Road Technology, Spon Press.

Lind, H. and Song, H. (2011) Dålig produktivitetsutveckling i byggindustrin: Ett faktum eller ett mätfel? KTH

Mandell, S. and Nilsson, J.-E. (2010) A Comparison of nit price and fixed price contracts for infrastructure construction projects. No 2010:13, Working Papers, Swedish National Road \& Transport Research Institute (VTI).

National Institute of Economic Research (2010) www.konj.se accessed on 28/4/1013

Ofori. G. (1992) 'The environment: the fourth construction project objective?', Construction Management and Economics, 10 (5), 369-395

Smith, K., Von Haefen, R, and Zhu, W. (1999) 'Do Environmental Regulations Increase Construction Costs for Federal-Aid Highways? A Statistical Experiment', Journal of Transportation and Statistics, 2 (1), 45-60. 
STA (2010) Swedish Transportation Administration annual report, www.trafikverket.se accessed on 28/4/2013

Warsame A (2011) 'Performance of Construction Projects: Essays on Supplier Structure, Construction Costs and Quality Improvement', Doctoral Thesis in Building and Real Estate Economics, KTH. 